\title{
Adult Craniopharyngioma Management: What's the Next Step?
}

\section{Sameh Elmorsy Hassan Elmorsy*}

El-Matrya Educational Hospita, Cairo University, Egypt

*Corresponding Author: Sameh Elmorsy Hassan Elmorsy, El-Matrya Educational Hospita, Cairo University, Egypt.
Received: January 26, 2020

Published: February 26, 2020

(C) All rights are reserved by Sameh

Elmorsy Hassan Elmorsy.

\section{Abstract}

A lot of troubles we are facing as neurological surgeons when we deal with this tumor. Although it's a benign tumor histologically, it has a malignant cellular characteristic, causes a big trouble in surgery and postsurgical treatment. It is divided into two types: adamantinomatous and papillary craniopharyngioma. The first surgical techniques for craniopharyngioma originated in 1891 by Selke. There is consensus that best management is surgery but there is trend developed recently between surgeons which is that subtotal resection is better to maintain function of surrounding structures, also total removal of this tumor surgically is challenging because of tight adherence of its capsule to lot of very important structures, In Best surgical hands this tumor is not favorable for resection because of multiple functional complications intraoperative and postoperative. Endocrine abnormalities are commonly seen postoperatively in the form of hypopituitarism. Immunotherapy including EGFR inhibitors such gefitinib, erlotinib, and lapatinib are now off-label use in treatment of craniopharyngiomas. In 2019 Rao., et al. reported treated case with selective BRAF inhibitor dabrafenib. Till now we didn't reach the ideal management for this benign tumor although surgery is the best. we need to take a different step in the direction of searching for better management of this tumor.

Aim and Type: This is short review to search in literature about ideal management for adult craniopharyngioma and what is the next step that we should talk to get better outcome.

Methodology: Different online medical databases have been reviewed to search for best management of this tumor including PubMed and Cochrane and authors surgical team experience

Conclusion: We need more studied in the future either surgically or immunologically to face this benign tumor to get less complications preoperative and postoperative to improve patients' outcome. we need to know what's is the next step of management.

Keywords: Craniopharyngioma; Adamantinomatous; Papillary Craniopharyngioma

\section{Introduction}

There was no definition of craniopharyngioma until Zenker described a mass along the pars distalis and pars tuberalis of the pituitary which is composed of squamous epithelial cells, In 1857 [1] then Luschka gets in depth and extensively researched adenohypophyseal squamous cells, in 1860 [2] then several researches comes after, Saxer [3] made a systematic study about adeno-hypophyseal squamous epithelial cells tumors, in 1902. Then Erdheim [4] reported that these cells only existed in the pituitary glands of adult patients in1904. several terms were used to describe this type of tumor, including hypophyseal duct tumor, craniopharyngeal duct tumor, Rathke's pouch tumor, interpeduncular and suprasellar tumors, craniobuccal cysts, suprasellar epithelioma, and adamantinoma.

In 1932, Cushing suggested the name craniopharyngioma for this tumor which takes its origin from epithelial rests which is due to an imperfect closure of the hypophyseal or craniopharyngeal duct [5]. Also Susman reported presence of squamous epithelial cells in the pituitary glands of pediatric patients in the same year [6]. 
Incidence and pathophysiology

Craniopharyngioma, accounts for $2-5 \%$ of all intracranial tumors [7]. Its also most common type of pituitary mass in children, accounts for $6-13 \%$ of all childhood brain tumors and about $50 \%$ of childhood sellar tumors [8-10].

There are three theories proposed to describe the etiology of craniopharyngioma. The first one proposes that craniopharyngiomas develop from the transformation of oral ectodermal embryologic remnants of the Rathke pouch, the other one says that this tumor originates from metaplasia of the primordial adenohypophysis cells $[11,12]$, last one says that it is a midline congenital tumor not different from an epidermoid cyst.

Although its benign tumor histologically, it has a malignant cellular characteristic, and causes a big trouble in surgery and postsurgical treatment.

It is divided into two types: adamantinomatous and papillary craniopharyngioma adamantinomatous is more common about $90 \%$ of all craniopharyngiomas mostly in children with features of various types of epithelial characteristics such as peripheral palisades, stellate reticulum, whorl-like array cells, wet keratin, cholesterol clefts, and contain mutations in CTNNB1, encoding $\beta$-catenin: a component of the adherents junction and mediator of Wnt signaling. reported frequency of CTNNB1 mutations varies widely (16 - 100\%).Papillary type mostly presented in adults and present as solid masses, histologically composed of sheets of well-differentiated squamous epithelial cells, with prominent papillae composed of squamous epithelial cells that grow around fibrovascular cores.

\section{Surgical management}

The first surgical techniques for craniopharyngioma originated in 1891 by Selke, then in 1907, the first successful transcranial approach performed by Horsley. Eiselsberg did the first successful resection of craniopharyngioma through a transsphenoidal approach by in 1910, improved by Halstead as a sublabial transsphenoidal resection in the same year. in 1919, Cushing developed and performed the first successful resection through the trans-lamina terminalis approach of a retrochiasmatic craniopharyngioma. Then, in 1924, he performed a transcallosal resection of a craniopharyngioma [5]. Different approaches developed to resect this tumor either transsphenoidal or transcranial. Although almost there are consensus that growth total resection of the tumor is the best chance for patient but there is trend developed recently between surgeons which is that subtotal resection is better to maintain function of surrounding structures, as it's benign histologically so it's better to leave some pieces especially in adults because its growth is slow, also total removal of this tumor surgically is challenging because of tight adherence of its capsule to lot of very important structures, in Best surgical hands this tumor is not favorable for resection because of multiple functional complications intraoperative and postoperative.

Endocrine abnormalities are commonly seen postoperatively in the form of hypopituitarism and it is reported with deficiencies of at least three pituitary hormones in 54 - 100\%. Preoperative endocrine deficits are not alleviated after surgery, though patients with diabetes insipidus may improve. Hypothalamic dysfunction may present as obesity, water balance impairment, loss of temperature control, sleep disorders, and neurocognitive disorders. Hypothalamic damage may result from tumor invasion, direct surgical injury, tumor recurrence, and radiation.

\section{Immunological management}

The epidermal growth factor receptor (EGFR) is expressed in craniopharyngiomas and its upregulation is implicated in cell differentiation, proliferation, apoptosis, and migration of these tumors [13]. Its expression reported in craniopoharyngioma and EGFR phosphorylation enhances adamantinomatous type cell migration thus its proposed as an escape mechanism for radiation therapy $[14,15]$. EGFR inhibitors such gefitinib, erlotinib, and lapatinib are now routine treatments in non-small cell lung cancer and breast cancer and could be considered for off-label use in craniopharyngiomas.

The response to BRAF inhibitors in papillary craniopharyngioma has shown promise, but the tumor recurs shortly after treatment interruption in most cases [16]. Subsequently, BRAF inhibition combined with the MEK inhibitor trametinib has shown a decrease in proliferation of tumor cells in vitro and in preclinical xenograft models and produced a dramatic response, triple combination of BRAF and MEK inhibitors plus immune checkpoint inhibitors are now tested to target this tumor genetically [17].

Mayank Rao., et al. 2019 reported a case of newly diagnosed papillary craniopharyngioma with BRAF V600E mutation treated with single-agent selective BRAF inhibitor dabrafenib. 


\section{Conclusion}

Till now we didn't reach the ideal management for this benign tumor in adults. Most of researches suggest that gross total resection of this tumor is the best chance for the patients but this option is accompanied by a lot of complications intraoperative and postoperative may be in the future we can find the way to separate this tumor from surrounding structures without causing these serious damage to its surrounding delicate tissues, may be also immunotherapy find us procedure to target this tumor from inside, so we need more steps in the future to face such tumors either surgically or immunologically to lessen serious complications of surgical intervention which till now is the best chance for these patients.

\section{Bibliography}

1. Raimondi AJ and Rougerie J. "A critical review of personal experiences with craniopharyngioma: clinical history, surgical technique and operative results". Pediatric Neurosurgery 21.2 (1994): 134-150.

2. Luschka H. "Der Gehirnhang und die Steissdruese des Menschen". Berlin: G. Reimer (1860).

3. Saxer F. "Ein Beitrag zur Kenntniss der Dermoide und Teratome”. Ziegler's Beitr (1902).

4. Erdheim J. "Über hypophysengangsgeschwulste und hirmcholesteatome". Sitzungsb Kais Akad Wissen Math Naturw Klin 113 (1904): 537-726.

5. Cushing H. "The craniopharyngioma Intralcranial tumors". London: Bailliere, Tindal and Cox (1932): 93-98.

6. Susman W. "Embryonic epithelial rests in the pituitary". British Journal of Surgery 19.76 (1932): 571-576.

7. Parisi JE and Mena H. "Nonglial tumors". Principles and practice of neuropathology". 1st ed. St. Louis, MO: Mosby (1993): 203-266.

8. Matson DD and Crigler JF. "Management of craniopharyngioma in childhood". Journal of Neurosurgery 30.4 (1969): 377390.

9. Schoenberg BS., et al. "The epidemiology of primary intracranial neoplasms of childhood. A population study". Mayo Clinic Proceedings 51.1 (1976): 51-56.
10. Kuratsu J and Ushio Y. "Epidemiological study of primary intracranial tumors in childhood. A population based survey in Kumamoto Prefecture, Japan". Pediatric Neurosurgery 25.5 (1996): 240-246.

11. Karavitaki N and Wass JA. "Non-adenomatous pituitary tumours". Best Practice and Research Clinical Endocrinology and Metabolism 23 (2009): 651-665.

12. Prabhu VC and Brown HG. "The pathogenesis of craniopharyngiomas". Childs Nervous System 21 (2005): 622-627.

13. Holsken A., et al. "EGFR signaling regulates tum or cell migration in craniopharyngiomas". Clinical Cancer Research 17 (2011): 4367-4377.

14. Gump JM., et al. "Identification of targets for rational pharmacological therapy in childhood craniopharyngioma". Acta Neuropathologica Communications 3 (2015): 30.

15. Stache C., et al. "Drug priming enhances radiosensitivity of adamantinomatous craniopharyngioma via downregulation of surviving". Neurosurgical Focus 41 (2016): E14.

16. Aylwin SJ., et al. "Pronounced response of papillary craniopharyngioma to treatment with vemurafenib, a BRAF inhibitor". Pituitary 19 (2016): 544-546.

17. Cynthia Kassab., et al. "Genetic and immune profiling for potential therapeutic targets in adult human craniopharyngioma". Clinical Oncology and Research Journal 2.3 (2019): 2-8.

\section{Assets from publication with us}

- Prompt Acknowledgement after receiving the article

- Thorough Double blinded peer review

- Rapid Publication

- Issue of Publication Certificate

- High visibility of your Published work

Website: https://www.actascientific.com/

Submit Article: https://www.actascientific.com/submission.php Email us: editor@actascientific.com

Contact us: +919182824667 